\title{
Genetic diversity and population structure of Brycon nattereri (Characiformes: Bryconidae): a Neotropical fish under threat of extinction
}

\author{
Bruno A. Galindo ${ }^{1}$, Dhiego G. Ferreira ${ }^{1}$, Caroline Apolinário-Silva ${ }^{2}$, \\ Mariana C. Terra ${ }^{1}$, Nícollas G. O. Aprígio ${ }^{1}$, Renata R. Ota ${ }^{3}$, Willian M. Ohara ${ }^{4}$, \\ Fernanda S. Almeida ${ }^{2}$ and Silvia H. Sofia ${ }^{2}$
}

\begin{abstract}
Brycon nattereri is an endangered Neotropical fish reported along conserved stretches of the upper Paraná, Tocantins and São Francisco rivers. Populations of this species have been very rare in some Paraná River sub basins. This study analyzes the genetic diversity and population structure of $B$. nattereri in a restricted area of occurrence recently identified in upper Paraná River basin. Seven microsatellite loci and 497 bp of D-Loop mitochondrial region were examined in 92 individuals from four points along the area of occurrence. Both molecular markers indicated a single population distributed along a stretch of the river approximately $80 \mathrm{~km}$ long. Although some of the data suggest an ancient bottleneck, current levels of genetic diversity ( $H_{E}=0.574$ and $h=0.616$ ) were similar to those of other species of the genus Brycon. The results suggest that the population of $B$. nattereri has been able to maintain satisfactory levels of genetic diversity, in spite of the small area of occurrence. These data have highlighted an important conservation area and action may prove essential to improve the quality of the environment, and especially the water and riparian plant life, if the area is to be managed and conserved efficiently.
\end{abstract}

Keywords: Conservation, Endangered species, Molecular markers, Population genetics, Pirapitinga.

Brycon nattereri é um peixe Neotropical ameaçado de extinção reportado para trechos conservados dos rios Paraná, Tocantins e São Francisco. Populações desta espécie têm sido muito raras em algumas sub-bacias do rio Paraná. Este estudo analisou a diversidade genética e a estrutura populacional de $B$. nattereri em uma área de ocorrência restrita recentemente identificada na bacia do alto rio Paraná. Sete locos microssatélites e 497 pb da região mitocondrial D-Loop foram examinados para 92 indivíduos de quatro pontos ao longo da área de ocorrência. Ambos os marcadores moleculares indicaram uma única população distribuída em um trecho de aproximadamente $80 \mathrm{~km}$ do rio. Embora alguns dados tenham sugerido um antigo gargalo genético, os atuais níveis de diversidade genética $\left(H_{E}=0,574, h=0,616\right)$ foram similares aos de outras espécies do gênero Brycon. Estes resultados sugerem que a população de $B$. nattereri tem mantido níveis satisfatórios de diversidade genética, apesar da pequena área de ocorrência. Estes dados destacaram uma importante área de conservação e ações podem melhorar a qualidade do ambiente, especialmente para a vida aquática e mata ciliar, se a área for eficientemente manejada e conservada.

Palavras-chave: Conservação, Espécies ameaçada, Genética de populações, Marcadores moleculares, Pirapitinga.

\section{Introduction}

It is widely acknowledged that comprehensive studies on the genetic diversity and structure of endangered species are both necessary and urgent if we are to undertake effective environmental conservation and management action ( $\mathrm{Wu}$ et al., 2015). As one of three levels of biodiversity recommended for the conservation of the planet, genetic diversity is

\footnotetext{
${ }^{1}$ Laboratório de Genética e Conservação (GECON), Universidade Estadual do Norte Paraná, Rua Portugal, 340, 86300-000 Cornélio Procópio, PR, Brazil. (BAG) bruno@uenp.edu.br, ㄴhttps://orcid.org/0000-0003-0517-1004, (DGF) dhiegouenp@gmail.com, (Dhttps://orcid. org/0000-0003-4375-6556 (corresponding author)

${ }^{2}$ Laboratório de Genética e Ecologia Animal (LAGEA), Departamento de Biologia Geral, Universidade Estadual de Londrina, Rod. Celso Garcia Cid, km 380, 86051-970 Londrina, PR, Brazil. (CAS) carolapolinario07@gmail.com @ohttps://orcid.org/0000-0001-5810234X, (MCT) marianauenp@gmail.com, Dhttps://orcid.org/0000-0002-2907-405X, (NGOA) aprigio.bio@hotmail.com, Dhttps://orcid. org/0000-0002-5142-5119, (FSA) fernandasa@uel.br, @ https://orcid.org/0000-0002-0130-5047, (SHS) shsofiabelh@gmail.com, (Dhttps:// orcid.org/0000-0002-3443-0696

${ }^{3}$ Programa de Pós-Graduação em Ecologia de Ambientes Aquáticos Continentais, Universidade Estadual de Maringá. Av. Colombo, 5790, 87020-900 Maringá, PR, Brazil. (RRO) renatarubia.ota@gmail.com, ㄴohttps://orcid.org/0000-0002-5743-2758

${ }^{4}$ Laboratório de Ictiologia da Amazônia Ocidental (LIAO), Departamento de Engenharia de Pesca, Universidade Federal de Rondônia, Rua da Paz, 4376, Lino Alves Teixeira, 76916-000 Presidente Medici, RO, Brazil. (WMO) ohara@unir.br, ○https://orcid.org/0000-0003-1684-4198
} 
thought to be essential if populations are to evolve in response to environmental changes (Reed et al., 2002), such as those resulting from anthropogenic disturbances. It is a well-known fact that small and isolated populations are more likely to suffer impaired genetic diversity, mainly due to the effects of genetic drift and inbreeding (Frankham et al., 2010). Anthropogenic disturbances can lead to changes in the environment that can result in the isolation and decline of natural populations and are now a major threat to numerous species throughout the world (Frankham et al., 2010; Allendorf et al., 2012).

In the Neotropical region, Brycon nattereri Günther, 1864 (Characiformes, Characidae, Bryconinae), popularly known as pirapitinga, is a fish species under threat of extinction and very sensitive to environmental changes (Mikich, Bérnils, 2004; Rosa, Lima, 2008). It is a rare species, restricted to the upper stretches of medium-sized rivers, especiallytributary channels of clear, well-oxygenated water with moderately fast rapids and well-preserved riparian vegetation (Vieira et al., 2005; Shibatta et al., 2007; Lima et al., 2008; Pompeu et al., 2009; Casarim et al., 2012). In general, B. nattereri has been reported as distributed over three basins: namely the upper stretches of the Paraná, Tocantins and São Francisco basins (Lima et al., 2008, 2017).

In the upper Paraná River basin, a tributary system heavily impacted by anthropogenic activities in the Neotropical region (Agostinho et al., 2005), B. nattereri has recently been reported in the Corumbá (Pavanelli et al., 2007), Tibagi (Shibatta et al., 2007), Grande (Pompeu et al., 2009; Belei, Sampaio, 2012; Casarim et al., 2012) and Ivaí rivers (Viana et al., 2013; Frota et al., 2016). Although some studies report a number of populations of $B$. nattereri (Belei, Sampaio, 2012; Vitorino Júnior et al., 2014), this species is very rare and has low abundance in tributaries of the upper Paraná River (Casarim et al., 2012; Viana et al., 2013; Frota et al., 2016), including the Paranapanema River subbasin (Shibatta et al., 2007). Oyakawa et al. (2009) drew attention to the fact that, although $B$. nattereri used to be an important fishing resource in the Brazilian southeast during the last century, natural populations seem to have become extinct in some of these basins.

According to various authors, urgent action to conserve this species should include the identification and conservation of areas with healthy populations in upper stretches of tributaries with riparian vegetation (Mikich, Bérnils, 2004; Lima et al., 2008; Rosa, Lima, 2008). Although B. nattereri is recognized as an endangered species (Lima et al., 2008; Rosa, Lima, 2008), its population genetics is still largely unknown. Population analysis data produced using nuclear and mitochondrial markers are present in the literature, but only for other species of the genus Brycon (Hilsdorf et al., 2002; Barroso et al., 2005; Sanches, Galetti-Jr, 2012; Ashikaga et al., 2015). Thus, in this context, understanding the genetic diversity and population structure of the few populations of $B$. nattereri known to exist in nature would be of great relevance for its preservation. Since this species is still assigned "vulnerable" status in the Brazilian list of endangered species (ICMBio, 2018), genetic data could support management actions that prevent higher levels of threat of extinction. In view of this, there is hope that management initiatives intended to protect its populations can still be implemented.

In discussing the urgent actions required to conserve $B$. nattereri and possible threats to its populations, this study examines the diversity and genetic structure of $B$. nattereri along a recently identified area of occurrence in one of the tributaries of the Paranapanema River, in the upper Paraná Basin. Since this species possibly performs short migratory movements (Vieira et al., 2005; Vitorino Júnior et al., 2014) and its occurrence in the studied river seems restricted to an upper stretch (without apparent obstacles), a single population would be expected to occur in this area, possibly still exhibiting some genetic diversity among individuals. The present study tested and discussed these hypotheses, aiming to provide information that could improve our knowledge of the genetics of this species and help in developing future management and conservation initiatives.

\section{Material and Methods}

Study area. Samples were collected along a stretch (approx. $80 \mathrm{~km}$ ) of the upper Laranjinha River (Fig. 1). The source of this river is in the municipality of Ventania, state of Paraná, southern Brazil, and it flows into the Cinzas River, a tributary on the left of the Paranapanema River, upstream of the Paraná River.

Since the Paranapanema River is currently fragmented by eleven hydroelectric dams (Britto et al., 2003), some studies have suggested that its dam-free tributaries, such as the Laranjinha and Cinzas rivers, could have great importance for the maintenance of ichthyofauna that still exists in the basin (Hoffmann et al., 2005; Lopes et al., 2007; Vianna, Nogueira, 2008). Based on this, a previous study, conducted by Galindo (2014), sought to understand the composition and distribution of the ichthyofauna in the Laranjinha River. In that study, seven sampling sites were chosen (B, D-J in Fig. 1) from the source to the mouth of the river (spaced about $50 \mathrm{~km}$ ), which were sampled seasonally (six times at each site) from October 2010 to April 2012, using gill nets (different mesh-sizes) and other methodologies (cast nets and sieves) in stretches of approximately $500 \mathrm{~m}$, including $48 \mathrm{~h}$ efforts. In addition to registering more than 100 species along the Laranjinha River, Galindo (2014) also identified an occurrence area not yet reported for $B$. nattereri. Interestingly, even after several collections, this species was found only at sites B (40 individuals from six collections) and D (five individuals, obtained in a single collection of six performed).

Specimen sampling and marking. In order to understand whether there are one or more populations of $B$. nattereri in this area as well as their current levels of genetic diversity, 


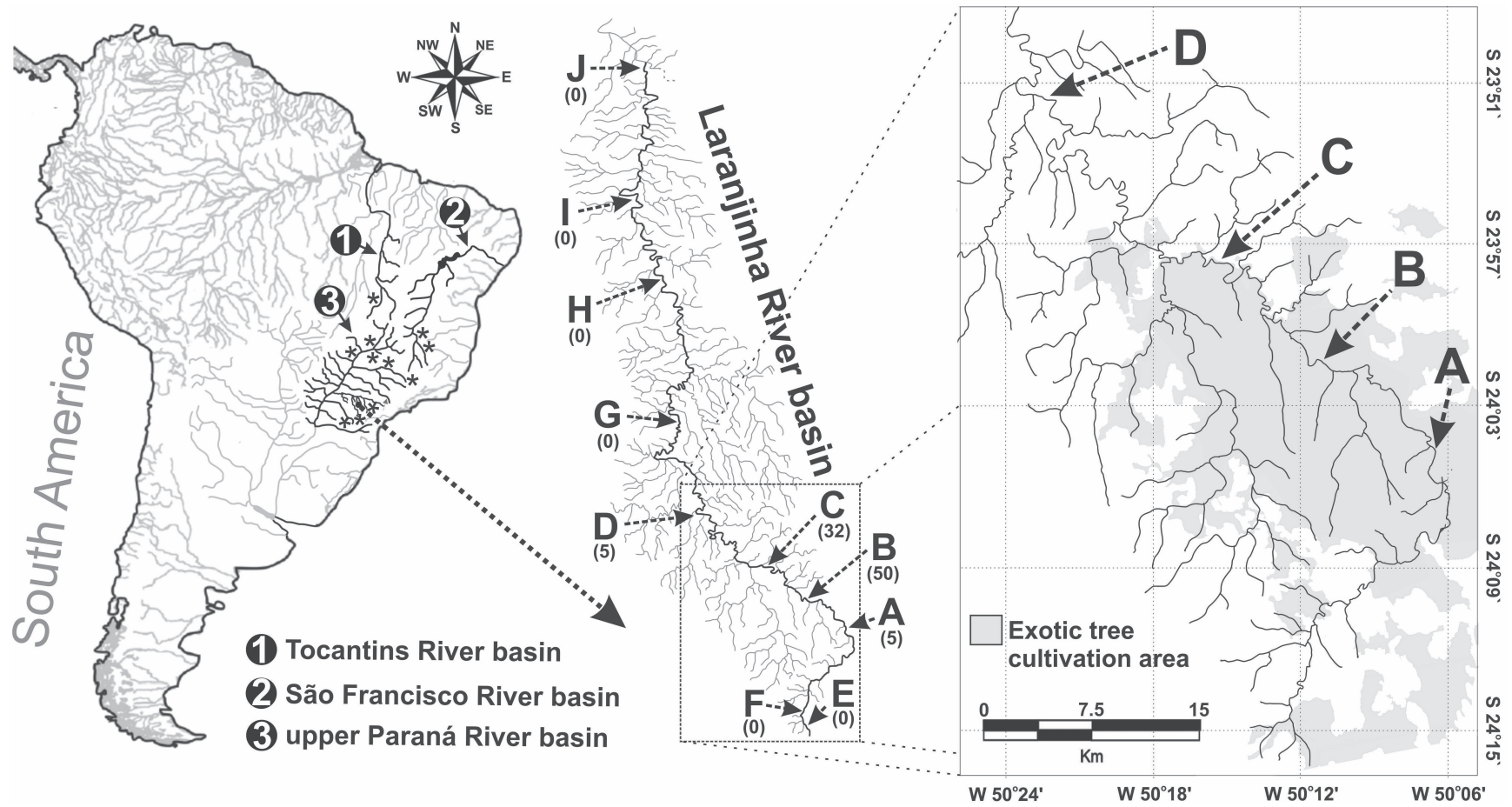

Fig. 1. Brycon nattereri sampling sites along the Laranjinha River (A, B, C and D). Also shown are the sampling sites used in a previous study (D, E, F, G, H, I and J) and the number of individuals of B. nattereri collected at each site (in parentheses). On the South America map, numbers and arrows indicate the Paraná, Tocantins, and São Francisco basins and the asterisks indicate the areas with records of Brycon nattereri (Rosa, Lima, 2008; Viana et al., 2013; Frota et al., 2016).

the present study carried out new samplings of $B$. nattereri at three sites with in the area of occurrence, including site B (site where the species was first found), site A (upstream of $\mathrm{B}$ and downstream of site $\mathrm{F}$, where the species was not found), and site $\mathrm{C}$ (downstream of $\mathrm{B}$ and upstream of $\mathrm{D}$, where the occurrence of the species was accidental) (Fig. 1).

Considering that there are no apparent barriers to fish migration within the study area, the locations of sites A and $\mathrm{C}$ were chosen aiming to perform samplings at equidistant sites (spaced about $20 \mathrm{~km}$ ), studying the stretch of river that still exhibits some characteristics commonly required by $B$. nattereri, such as good quality water and preserved riparian vegetation (Lima et al., 2008; Pompeu et al., 2009). In fact, although this stretch is fenced in for the cultivation of exotic trees, it still has some riparian vegetation (composed of native plants), which looks better than in other parts of the river. In addition, sites $\mathrm{A}$ and $\mathrm{C}$ were those with the best access conditions to the river, since the relief (Valleys) also presented limitations to sampling in other sections.

New samplings were performed seasonally (four times at each site) at sites A, B, and C, from July 2014 to March 2015 , using specific gill nets for $B$. nattereri (15 to $50 \mathrm{~mm}$ between knots), put in place for $24 \mathrm{~h}$ and checked every two hours. After obtaining a small sample of pelvic fin, the individuals captured were microchipped to prevent resampling and rapidly released into the environment. All samples were collected under Environmental Authorization Number 23315-1, issued by SISBIO/MMA. Dead specimens were deposited in the fish collection kept by the Museu de Zoologia, Universidade Estadual de Londrina under catalog number: MZUEL 9445-9446.

After the additional samplings, a total of 92 individuals was analyzed in the genetic study, obtained in the new samplings and by Galindo (2014), including: five from "site A" (all from new samplings), 50 from "site B" (40 from previous study and 10 from new samplings), 32 from "site C" (all from new samplings), and five from " $D$ " (all from previous study).

DNA extraction and quantification. Genomic DNA was obtained from pelvic fin clips using phenol/chloroform extractions (Almeida et al., 2001). DNA concentrations were determined using a Qubit fluorometer (Invitrogen) and samples were diluted to $5 \mathrm{ng} / \mu \mathrm{L}$.

Microsatellite markers. Cross-amplification tests were conducted from primer pairs available for other species of the genus Brycon, allowing the use of seven loci: four of B. opalinus, BoM 02, BoM05, BoM06, and BoM13 (Barroso et al., 2003), two of B. hilarii, Bh06 and Bh13 (Sanches, Galetti-Jr, 2006), and one of B. cephalus, Bc48-6 (Matsumoto, Hilsdorf, 2009). Reagent concentrations and PCR conditions were performed according to Ferreira et al. (2015), using the modifications proposed by Schuelke (2000). The annealing temperatures of successful cross-amplification loci were $45^{\circ} \mathrm{C}$ (BoM06), $48^{\circ} \mathrm{C}$ (BoM13 and $\left.\mathrm{Bh} 06\right), 50^{\circ} \mathrm{C}$ (BoM 02), 53.3 ${ }^{\circ} \mathrm{C}$ (BoM05) 
and $56^{\circ} \mathrm{C}$ (Bh13 and $\mathrm{Bc} 48-6$ ). Individual genotyping was performed in ABI 3500-XL automated sequencer (Applied Biosystems, Foster City, CA, USA), using the GeneScan 600 Liz (Applied Biosystems) molecular weight marker. Genotypes were determined using GeneMarker 1.85 software (Soft Genetics, State College, PA, USA).

mtDNA (D-Loop) haplotypes. The primers L 5'-AGAGCGTCGGTCTTGTAAACC-3' (Cronin et al., 1993) and H 5'-CCTGAAGTAGGAACCAGATG-3' (Meyer et al., 1990) were used to amplify and sequence a portion of the D-loop region of the mitochondrial DNA in all individuals studied. PCR and sequencing reactions were performed according to Ferreira et al. (2015). Sequences were obtained in ABI-PRISM $3500 \mathrm{XL}$ automated sequencer and aligned using the ClustalW application (Thompson et al., 1994) in the BioEdit v.7.1.3.0 program (Hall, 1999). Haplotype sequences were deposited in GenBank (MF377398-MF377402).

Population structure analyses. Since the null hypothesis would be the presence of a single population along the area of occurrence, the first analyses tested the genetic structuring between the samples, allowing understanding as to whether there are one or more populations. In a first step, microsatellite data were evaluated on a Bayesian cluster analysis in Structure v.2.3.3 (Pritchard et al., 2000), estimating the posterior probabilities for $K$ clusters, assuming HWE conditions within clusters while minimizing linkage disequilibrium. This analysis allows inference of which population an individual belongs to, regardless of their collection site. It includes an "attribution method" which calculates the probability of the different genotypes being observed in each population (without any a priori inference) and assigns the individuals to the populations, according to the possibilities of the genotypes belonging to them (Beaumont, Rannala, 2004).

In Structure v.2.3.3, twenty replicates were run for each $K$ value (number of clusters), which ranged from one to seven ( $K=1-7$, number of sampling sites plus three), according to Evanno et al. (2005). Each replicate was implemented by running 100,000 Markov Chain Monte Carlo (MCMC) iterations discarded as burn-in, followed by 1,000,000 MCMC iterations. Convergent values of key summary statistics were used to obtain an accurate estimate of $K$, according to Pritchard et al. (2000). Estimates of posterior sample distribution were obtained using the admixture model and correlated allele frequencies among populations. Log-likelihood values for data conditional on $K, \ln \operatorname{Pr}(X / K)$ (Pritchard et al., 2000 ), and $\Delta K$ ad hoc statistics (Evanno et al., 2005) were used to choose the most likely number of clusters $(K)$ using Structure Harvester v.0.6.7 (Earl, von Holdt, 2012). Results of independent Structure runs were summarized for the best $K$ using the "greedy" algorithm in Clumpp 1.1.2 (Jakobsson, Rosenberg, 2007). Graphs representing the membership coefficient of each sampled individual were plotted using Distruct 1.1 (Rosenberg, 2004).
Additionally, absence of genetic differentiation was also tested from the Analysis of Molecular Variance (AMOVA). This analysis was run on both molecular markers in the Arlequin v.3.5.1.3 program (Excoffier, Lischer, 2010), estimating the partitioning of genetic variation within and between samples. AMOVA also provided the general $\Phi_{\mathrm{ST}}$ values (a genetic differentiation index). Estimates of significance were conducted based on 10,000 permutations.

Genetic diversity analyses. After defining the number of existing populations in the study area, analyses were carried out to estimate the genetic diversity levels in the sample set. The total allele number $(A)$, average alleles per locus $\left(N_{A}\right)$, average effective alleles $\left(N_{E}\right)$, private allele number $\left(N_{p}\right)$, observed heterozygosity $\left(H_{\mathrm{O}}\right)$ and expected heterozygosity $\left(H_{\mathrm{E}}\right)$ were estimated using the Popgen v.1.31 program (Yeh et al., 1999). The Fstat v.2.9.3 program (Goudet, 2001) was used to estimate the rate of inbreeding $\left(F_{\text {IS }}\right)$. Testing for deviations from the Hardy-Weinberg Equilibrium (HWE) and linkage disequilibrium was performed using the Genepop v. 1.2 program (Raymond, Rousset, 1995), and alpha values adjusted using sequential Bonferroni corrections (Rice, 1989). Micro-Checker v.2.2.1 program (Van Oosterhout et al., 2004) was employed to evaluate null alleles or genotyping errors, such as allelic dropout and stutter peaks.

For mtDNA analysis, estimates of haplotype number, haplotype diversity $(h)$ and nucleotide diversity $(\pi)$ were obtained from DnaSP v.5 program (Librado, Rozas, 2009). The Network v.4.6.1.1 program (Fluxus Technology Ltd - http:// www.fluxus-engineering.com) was used to construct haplotype networks from mtDNA data based on the median-joining algorithm (Bandelt et al., 1999).

Demographic analyses. Since bottleneck tests are important to understand whether current levels of genetic diversity in a population were influenced by some decline in effective population size (Luikart, Cornuet, 1998), these tests were run on both molecular markers. Recent population bottleneck signs were evaluated on microsatellite data using Bottleneck v.1.2.02 program (Piry et al., 1999), considering deviations from the mutation-drift equilibrium. Three tests were used, including two tests to indicate bottlenecks in the presence of significant excess heterozygosity: "Sign test" (Cornuet, Luikart, 1996) and the "Wilcoxon sign-rank test" (Luikart, Cornuet, 1998), both based on the Infinite Alleles Model (IAM), Stepwise Mutation Model (SMM) and Two-Phase Model (TPM - with 90\% SMM and 10\% IAM), with a P-value $<0.05$. The third test was the "Mode-shift test" that indicates bottlenecks resulting from alterations in allele frequency distributions (Luikart et al., 1998).

In order to evaluate bottleneck signs (ancient or recent) on mtDNA data, Arlequin v.3.5.1.3 program (Excoffier, Lischer, 2010) was used to conduct the selective neutrality tests based on the infinite sites model of Tajima $(D)$ (Tajima, 1989) and Fu $(F s)(\mathrm{Fu}, 1997)$, and the mismatch distribution analysis, using the sudden expansion model (Rogers, Harpending, 1992). 


\section{Results}

Population structure. All results corroborate the existence of a single population in the study area. Bayesian clustering analysis (Structure) used on the microsatellite data showed that the most probable $K(K=$ cluster number) was $K=1$ from $\ln \operatorname{Pr}(X / K)$ and $K=2$ from $\Delta K$ (Figs. 2a, b). Since the $\Delta K$ cannot find the best $K$ if $K=1$ (Evanno et al., 2005), the graphic representation (Fig. 2c) was presented using $K=2$ (the lowest possible $K$ from $\Delta K$ ) aiming to show that although it displays individuals with contrasting ancestry values (some with $\mathrm{q}<$ 0.8 ), there was no clearly defined clustering and ancestry values were evenly distributed over the samples.

Additionally, AMOVA analysis showed that, in terms of both the nuclear DNA and the mtDNA, most of the variation occurred within populations $(99.74 \%$ and $99.04 \%$, respectively) and a small percentage between samples $(0.26 \%$ and $0.95 \%$, respectively). In both cases, $\Phi_{\mathrm{ST}}$ values were not significant (nuclear DNA: $\Phi_{\mathrm{ST}}=0.0026$, P-value $>0.05$, and mtDNA: $\Phi_{\mathrm{ST}}=0.0094$, P-value $>0.05$ ), corroborating the absence of genetic structuring among the samples.

a)
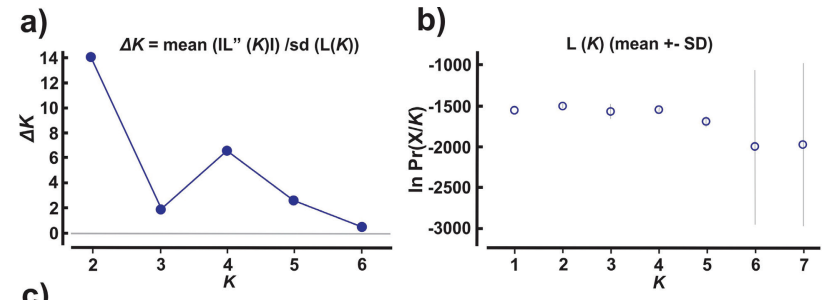

c)

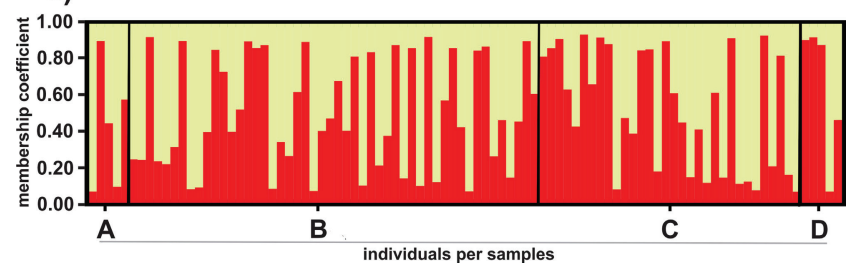

Fig. 2. Bayesian analysis results (Structure). a. Values of $K$ obtained based on $\Delta K$. b. Values of $K$ obtained based on mean likelihood Ln $(K)$. c. Graphic representation of $K=2$. Each column represents a different individual and the colors denote the probable ancestry coefficient of the individual and each genetic cluster.

Genetic diversity. After genetic structure results, all analyzes were conducted considering the existence of a single population. In all, 48 microsatellite alleles were obtained, average 6.857 alleles per locus. The average effective alleles $\left(N_{\mathrm{E}}\right)$ was 3.036 , expected heterozygosity $\left(H_{\mathrm{E}}\right) 0.574$, and observed $\left(H_{\mathrm{O}}\right)$ heterozygosity 0.564 . The inbreeding coefficient was not significant, $F_{\text {IS }}=0.024$, P-value $>0.05$. After applying Bonferroni sequential correction, there were no significant deviations $(\mathrm{P}<0.05)$ in the Hardy-Weinberg equilibrium (HWE) of any of the microsatellite loci. This correction was also applied to the linkage disequilibrium (LD) tests, and significant values were found only between loci BoM05 and BoM06. The Micro-Checker program fou- nd no null alleles among the seven loci used.

A $555 \mathrm{bp}$ fragment, including $497 \mathrm{bp}$ from the D-loop mitochondrial region and $58 \mathrm{bp}$ from the tRNA-Pro gene, was amplified and sequenced for the 92 individuals. A total of four polymorphic sites were found, revealing five different haplotypes (MF377398-MF377402). The only singleton was haplotype H5. The haplotype $(h)$ and nucleotide $(\pi)$ diversity values were 0.616 and 0.0014 , respectively.

The haplotype network showed few mutational steps among the haplotypes found. H1 was the most frequent haplotype and was found in all samples (Fig. 3).

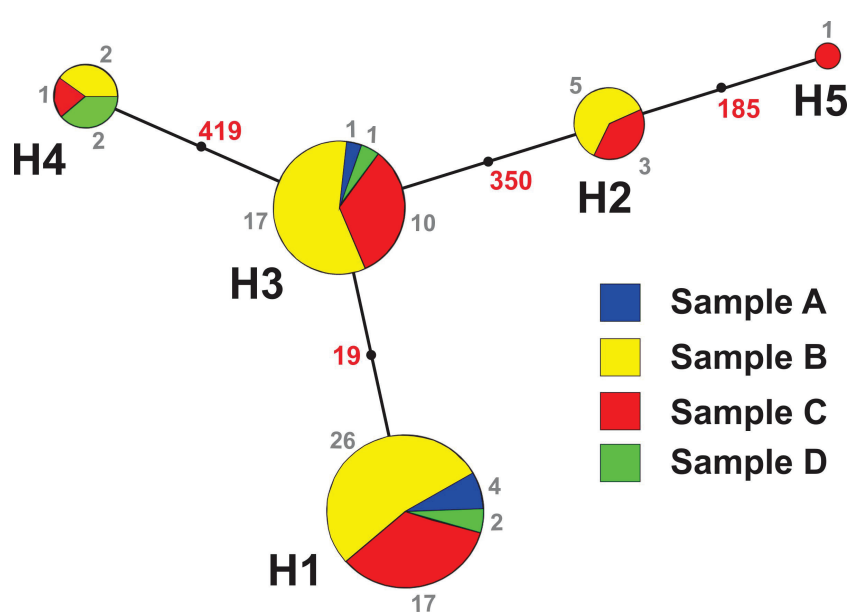

Fig. 3. Haplotype network based on partial sequencing of the D-loop region (mtDNA) of 92 individuals of Brycon nattereri from the Laranjinha River. Circle sizes are proportional to haplotype frequency.

Demographic analysis. Microsatellite data analysis revealed signs of a recent bottleneck only in the IAM model of the Wilcoxon signed-rank test, with significant values for excess heterozygosity (Tab. 1).

Tab. 1. Bottleneck tests on the population of B. nattereri from the Laranjinha River. Sign test and Wilcoxon signedrank test for excess heterozygosity, and mode-shift test for allelic frequency distribution patterns. $H_{e}$ - number of loci exhibiting excess heterozygosity; $H_{d}-$ number of loci exhibiting deficient heterozygosity. ${ }^{*}$ Significant values for excess heterozygosity $(\mathrm{P}<0.05) .{ }^{a}$ Infinite allele model, ${ }^{\mathrm{b}}$ Two phase model (90\% SSM) and ${ }^{\mathrm{c}}$ Stepwise mutation model.

\begin{tabular}{|c|c|c|c|c|c|c|}
\hline \multirow{2}{*}{ Bottleneck Tests } & \multicolumn{2}{|c|}{ IAM $^{\mathrm{a}}$} & \multicolumn{2}{|c|}{$\mathrm{TPM}^{\mathrm{b}}$} & \multicolumn{2}{|c|}{$\mathrm{SMM}^{\mathrm{c}}$} \\
\hline & $H_{e} / H_{d}$ & $P$ & $H_{e} / H_{d}$ & $P$ & $H_{e} / H_{d}$ & $P$ \\
\hline Sign test & $5 / 2$ & 0.269 & $2 / 5$ & 0.110 & $2 / 5$ & 0.129 \\
\hline Wilcoxon sign-rank test & & $0.019^{* \mathrm{e}}$ & & 0.945 & & 0.988 \\
\hline
\end{tabular}

Allele frequency distribution: L-shaped (non-bottlenecked population).

The signed-rank test did not produce significant values in any of the mutational models (IAM, SSM or TPM) and the mode-shift test showed typical L-shaped distribution (no bottleneck) in allele frequency (Tab. 1). The values in the $\mathrm{Fu}(F s=-0.194)$ and Tajima $(D=0.059)$ tests were not signi- 
ficant (P-values $>0.05)$. Furthermore, the mismatch distribution graph (Fig. 4) showed unimodal distribution for all haplotype frequencies.

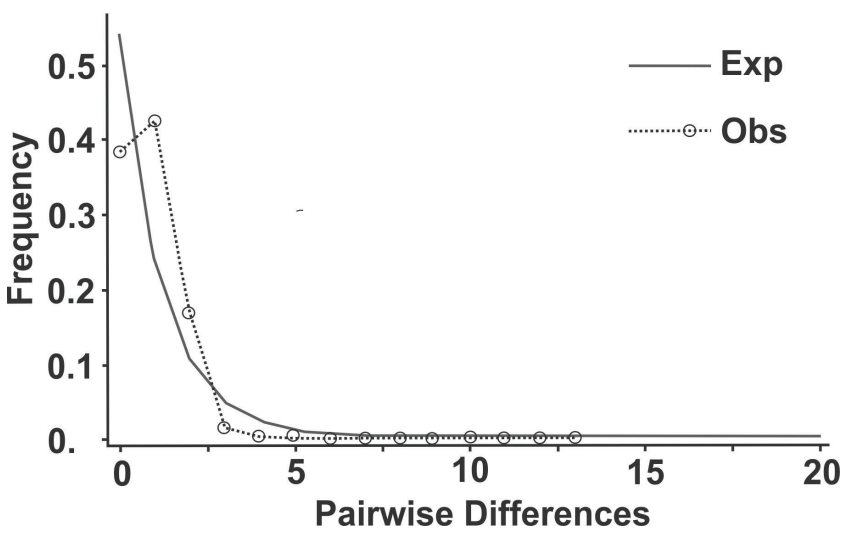

Fig. 4. Mismatch distribution for mitochondrial haplotypes for 92 individuals of Brycon nattereri from the Laranjinha River.

\section{Discussion}

The genetic information obtained in this study indicates the existence of a single population of $B$. natterer in the study area, showing satisfactory levels of genetic diversity and the absence of significant genetic structuring. In the case in point, the absence of natural or man-made barriers, as well as the presence of rapids, both acknowledged as important characteristics for the occurrence of B. nattereri (Lima et al., 2008; Vitorino Júnior et al., 2014), together with the restricted size of the area of occurrence, are possible factors that may account for the presence of a single population.

Despite the lack of information on the genetic diversity and population structure of $B$. nattereri, the majority of genetic studies conducted on other Brycon species show higher levels of genetic structure, influenced by reproductive behaviors (Sanches, Galetti-Jr, 2007, 2012; Sanches et al., 2012), geographic distance, natural barriers or anthropogenic interference (Hilsdorf et al., 2002; Barroso et al., 2005; Matsumoto, Hilsdorf, 2009; Ashikaga et al., 2015). For $B$. nattereri, non-genetic studies have revealed that this species exhibits seasonal patterns of reproduction and migratory movements restricted to short river stretches, mainly in source regions (Vieira et al., 2005; Vitorino Júnior et al., 2014). Interestingly, despite the fact that $B$. natterer $i$ is an endangered species (Lima et al., 2008; Rosa, Lima, 2008), the data in our study, and especially the levels of genetic diversity $\left(A=48, N_{A}=6.857\right.$ and $\left.H_{E}=0.574\right)$, the absence of inbreeding, non-significant sub structuring and the lack of HW disequilibrium, all suggest that the sampled population has been able to maintain satisfactory population size over a limited stretch (approx. $80 \mathrm{~km}$ ) of the river.

The genetic diversity indices derived from both molecular markers indicate that the population of $B$. nattereri in the Laranjinha River exhibits estimated values (such as $H_{E}$ and $h$ ) within the limits of variation reported for the genus
Brycon. This has been shown to be the case for other endangered species, such as $B$. opalinus, $B$. insignis and $B$. orbignyanus $\left(H_{\mathrm{E}}=0.486\right.$ to 0.892 and $h=0.405$ to 1.000 ) (Hilsdorf et al., 2002; Barroso et al., 2003, 2005; Matsumoto, Hilsdorf, 2009; Ashikaga et al., 2015), and also for species not yet classified as under threat, such as $B$. hilarii and $B$. sinuensis $\left(H_{\mathrm{E}}=0.660\right.$ to 0.740$)$ (López, 2006; Sanches, Galetti-Jr, 2007, 2012). Thus, although the population of $B$. nattereri studied herein exhibited a low $\pi(0.0014)$ and only five haplotypes, estimates of $H_{E}$ and $h$ seem satisfactory. According to Freeland (2005), $h$ is considered the haploid equivalent of $H_{E}$ in data on diploids. Therefore, the similarity among these estimates suggests that the current variations in nuclear and mitochondrial DNA are evenly distributed throughout the population.

Additionally, microsatellite date analysis showed very weak evidence of recent bottlenecks in the population studied (only in the IAM model of Wilcoxon sign-rank test). However, despite the positive current scenario of this population (absence of recent bottlenecks and satisfactory $H_{E}$ and $h$ ), some results, mainly from mtDNA, suggest that an ancient bottleneck could have affected its genetic composition in the past (Slatkin, Hudson, 1991; Rogers, Harpending, 1992; Grant, Bowen, 1998). Examination of 497 bp in the D-Loop region, one of most variable regions of mtDNA (Frankham et al., 2010; Santos et al., 2007), revealed only five haplotypes and $0.14 \% \pi$ in over ninety individuals. Patterns containing low $\pi$ values $(<0.5 \%)$ combined with high $h$ values ( $>0.5)$ usually suggest the occurrence of a bottleneck followed by rapid population growth and an accumulation of mutations (Grant, Bowen, 1998). In this scenario, the current levels of genetic diversity of $B$. nattereri seem to be in a process of recovery, which has been happening faster in microsatellite loci than in mtDNA.

Mutation rates in microsatellite loci are acknowledged to be higher than those in mtDNA (Estoup, Angers, 1998; Santos et al., 2007). Furthermore, in contrast to mtDNA, nuclear loci exhibit biparental inheritance and allow different alleles to be distributed and combined at higher rates (Freeland, 2005; Allendorf et al., 2012). Thus, signs of ancient bottlenecks can be less evident in microsatellite loci, since they tend to recover from variation more rapidly than mitochondrial sequences. At the same time, the recovery of $\pi$ after a genetic bottleneck is slower than $h$ in mtDNA (McCusker, Bentzen, 2010). Therefore, although $h$ in B. nattereri seems to be recovering, $\pi$ still seems to show signs of a dramatic drop in population that occurred in the past. Although this study does not reveal significant values for Tajima's $D$ test and Fu's Fs test, the fact that a star-shaped haplotype network was obtained suggests population expansion after a bottleneck (Slatkin, Hudson, 1991; Grant, Bowen, 1998), indicating that all the current haplotypes are closely related (three mutations at most) and derived from a single main haplotype (H1). In addition, the pattern of mismatch distribution is unimodal, which is usually ascribed to recent population expansion processes (Rogers, Harpending, 1992), 
including the accumulation of mutations with minimum loss of lineage (Cassone, Boulding, 2006).

In fact, $B$. nattereri was not the first fish species to show signs of an ancient bottleneck in the study area. Ferreira et al. (2015) studied the pearl cichlid Geophagus brasiliensis (Quoy, Gaimard, 1824) at numerous points along the Laranjinha River and found a considerable drop in the genetic diversity of a sample obtained from point "B". In addition, as in our study, the ancient reduction in effective population size was less evident in the microsatellite data than in the mtDNA data. In another study, Galindo (2014) examined samples of the armored catfish Hypostomus ancistroides (Ihering, 1911) at numerous points along the same river, and its estimated genetic diversity was also lower at point "B". Despite the similarity of results obtained in the study area, we are still not in a position to discuss the factors that led to an ancient bottleneck.

It is a matter of some urgency to identify and conserve areas with healthy populations of $B$. nattereri (Mikich, Bérnils, 2004; Lima et al., 2008; Rosa, Lima, 2008). This study provides information on a recently identified area of occurrence of $B$. nattereri and shows that the population in this location still retains satisfactory levels of genetic diversity. Although further study is required on this population, including the analysis of ecological and reproductive aspects, the data obtained herein constitute essential information for drafting future management and conservation initiatives. In addition to being an endangered species, $B$. nattereriis very demanding and requires well-conserved areas with good quality water and preserved riparian vegetation (Lima et al., 2008; Pompeu et al., 2009). Therefore, action taken to research, elucidate and improve the environmental quality of the Laranjinha River basin could make a significant contribution to conserving $B$. nattereri population and its genetic diversity levels.

As the Laranjinha River basin stands at present, the main threats to the conservation of $B$. nattereri seem to be related to recent or future anthropogenic impacts. Therefore, the main actions for conserving this species should include: a) improving and maintaining water quality. During our sampling operations, activities that routinely influence water quality, such as the use of agrochemicals and discharge of domestic and industrial waste, were observed both upstream and downstream of the area of occurrence; b) preservation and recovery of riparian vegetation. Despite the presence of some riparian vegetation along the sampled stretch, this has been fenced in for the cultivation of exotic trees. Furthermore, the recovery and expansion of riparian vegetation could also help expand the area of occurrence of $B$. nattereri, as has already been suggested for other species of the genus Brycon (Gomiero, Braga, 2007; Gomiero et al., 2008; Matsumoto, Hilsdorf, 2009; Vitorino Júnior et al., 2014); c) prohibition of hydroelectric dams. Although not present in the study area, a number of projects for the construction of small hydropower stations may pose a threat to the Laranjinha River (Agência Nacional de Energia Elétrica, 2015).
To conclude, the data herein indicate that the population of $B$. nattereri identified in the Laranjinha River (upper Paraná River) still retains satisfactory levels of genetic diversity and that this genetic diversity is evenly distributed in the area of occurrence. Measures including the aforementioned actions could help manage and conserve this population. At present, additional activities such as repopulation do not seem necessary. However, long-term monitoring of genetic diversity and inbreeding could help conserve this population and provide a basis for future decision-making.

\section{Acknowledgments}

Our thanks to the "Fundação Grupo Boticário de Proteção à Natureza" (FBPN) and the "Fundação Araucária" for the funding provided; "Florestal Vale do Corisco" and "Florestal Klabin" for their support during sampling operations; the State University of North Paraná (UENP) for financial and logistical support; Dr. Oscar Akio Shibatta (State University of Londrina) for his help in identifying the species studied and IBAMA (Brazilian Environmental and Natural Resources Institute)/ICMBio-System (Chico Mendes Institute-MMA) for granting permission to collect samples.

\section{References}

Agência Nacional de Energia Elétrica. Relatório de Acompanhamento de Estudos e Projetos de Usinas Hidrelétricas; 2015 [cited 2018 Sep 18]. Available from: http://www.aneel.gov.br/ area.cfm?idArea $=428$

Agostinho AA, Thomaz SM, Gomes LC. Conservation of the biodiversity of Brazil's inland waters. Conserv Biol [serial on the internet]. 2005; 19(3):646-52. Available from: http://dx.doi. org/10.1111/j.1523-1739.2005.00701.x

Allendorf FW, Luikart GH, Aitken SN, editors. Conservation and the Genetics of Populations. Oxford: Wiley Blackwell Publishing; 2012.

Almeida FS, Fungaro MHP, Sodré LMK. RAPD and isoenzyme analysis of genetic variability in three allied species of catfish (Siluriformes: Pimelodidae) from the Tibagi River, Brazil. J Zool [serial on the internet]. 2001; 253(1):113-20. Available from: https://doi.org/10.1017/S0952836901000103

Ashikaga FY, Orsi ML, Oliveira C, Senhorini JA, Foresti F. The endangered species Brycon orbignyanus: genetic analysis and definition of priority areas for conservation. Environ Biol Fish [serial on the Internet]. 2015; 98(7):1845-55. Available from: https://doi.org/10.1007/s10641-015-0402-8

Bandelt HJ, Forster P, Röhl A. Median-joining networks for inferring intraspecific phylogenies. Mol Biol Evol [serial on the Internet]. 1999; 16(1):37-48. Available from: https://doi. org/10.1093/oxfordjournals.molbev.a026036

Barroso RM, Hilsdorf AWS, Moreira HLM, Cabello PH, TraubCseko YM. Genetic diversity of wild and cultured populations of Brycon opalinus (Cuvier, 1819) (Characiforme, Characidae, Bryconiae) using microsatellites. Aquaculture [serial on the Internet]. 2005; 247(1-4):51-65. Available from: https://doi. org/10.1016/j.aquaculture.2005.02.004

Barroso RM, Hilsdorf AWS, Moreira HLM, Mello AM, Guimarães SEF, Cabello PH, Traub-Cseko YM. Identification and 
characterization of microsatellites loci in Brycon opalinus (Cuvier, 1819) (Characiformes, Characidae, Bryconinae). Mol Ecol Notes [serial on the Internet]. 2003; 3(2):297-98. Available from: https://doi.org/10.1046/j.1471-8286.2003.00435.x

Beaumont MA, Rannala B. The Bayesian revolution in genetics. Nat Rev Genet [serial on the Internet]. 2004; 5:251-61. Available from: https://doi.org/10.1038/nrg1318

Belei F, Sampaio WMS. Ictiofauna do rio Lourenço Velho, afluente do rio Grande: pequena diversidade, grande importância para a conservação de uma espécie ameaçada. Evol Conserv Biodivers. 2012; 3(1):14-27.

Britto SGC, Sirol RN, Vianna NC, Jardim SM, Santos JC, Pelisari E. Peixes do rio Paranapanema. São Paulo: Duke Energy; 2003.

Casarim R, Bueno ML, Pompeu PS. Ichthyofauna of the Aiuruoca River basin, Minas Gerais, Brazil. Check List [serial on the Internet]. 2012; 8(6):1166-71. Available from: http://dx.doi. org/10.15560/8.6.1166

Cassone BJ, Boulding EG. Genetic structure and phylogeography of the lined shore crab, Pachygrapsus crassipes, along the northeastern and western Pacific coasts. Mar Biol [serial on the Internet]. 2006; 149(2):213-26. Available from: https://link. springer.com/article/10.1007/s00227-005-0197-9

Cornuet JM, Luikart G. Description and power analysis of two tests for detecting recent population bottlenecks from allele frequency data. Genetics. 1996; 144(4):2001-14.

Cronin MA, Spearman WJ, Wilmot RL, Patton JC, Bickham JW. Mitochondrial DNA variation in chinook (Oncorhynchus tshawytscha) and chum salmon (O. keta) detected by restriction enzyme analysis of polymerase chain reaction (PCR) products. Can J Fish Aquat Sci [serial on the Internet]. 1993; 50(4):70815. Available from: https://doi.org/10.1139/f93-081

Earl DA, von Holdt BM. STRUCTURE HARVESTER: A website and program for visualizing STRUCTURE output and implementing the Evanno method. Conserv Genet Resour [serial on the Internet]. 2012; 4(2):359-61. Available from: http://dx.doi.org/10.1007/s12686-011-9548-7

Estoup A, Angers B. Microsatellites and mini satellites for molecular ecology: theoretical and experimental considerations. In: Carvallo GR, editor. Advances in molecular ecology. Amsterdam: NATO Press; 1998. p.55-86.

Evanno G, Regnaut S, Goudet DJ. Detecting the number of clusters of individuals using the software structure: A simulation study. Mol Ecol [serial on the Internet]. 2005; 14(8):2611-20. Available from: https://doi.org/10.1111/j.1365-294X.2005.02553.x

Excoffier L, Lischer HEL. Arlequin suite ver 3.5: A new series of programs to perform population genetics analyses under Linux and Windows. Mol Ecol Resour [serial on the Internet]. 2010; 10(3):564-67. Available from: https://doi.org/10.1111/j.17550998.2010.02847.x

Ferreira DG, Galindo BA, Frantine-Silva W, Almeida FS, Sofia SH. Genetic structure of a Neotropical sedentary fish revealed by AFLP, microsatellite and mtDNA markers: a case study. Conserv Genet [serial on the Internet]. 2015; 16(1):151-66. Available from: https://link.springer.com/article/10.1007\%2 Fs 10592-014-0648-2

Frankham R, Ballou JD, Briscoe DA. Introduction to conservation genetics. 2nd ed. Cambridge: Cambridge University Press; 2010.

Freeland JR. Molecular ecology. Chichester: John Wiley \& Sons Ltd; 2005.

Frota A, Deprá GC, Petenucci LM, Graça WJ. Inventory of the fish fauna from Ivaí River basin, Paraná State, Brazil. Biota Neotropica [serial on the Internet]. 2016; 16(3):e20150151. Available from: http://dx.doi.org/10.1590/1676-0611-BN-2015-0151

$\mathrm{Fu}$ YX. Statistical test of neutrality of mutations against population growth, hitchhiking d background selection. Genetics. 1997; 147(2):915-25.

Galindo BA. Diversidade de peixes do rio Laranjinha - alto rio Paraná. [PhD Thesis]. Londrina, PR: Universidade Estadual de Londrina; 2014.

Gomiero LM, Braga FMDS. Reproduction of Pirapitinga do Sul (Brycon opalinus Cuvier, 1819) in the Parque Estadual da Serra do Mar-Núcleo Santa Virgínia, São Paulo, Brazil. Braz J Biol [serial on the internet]. 2007; 67(3):541-49. Available from: http://dx.doi.org/10.1590/S1519-69842007000300021

Gomiero LM, Manzatto AG, Braga FMDS. The role of riverine forests for food supply for the omnivorous fish Brycon opalinus Cuvier, 1819 (Characidae) in the Serra do Mar, Southeast Brazil. Braz J Biol [serial on the internet]. 2008; 68(2):321-28. Available from: http://dx.doi.org/10.1590/ S1519-69842008000200013

Goudet J. FSTAT, a program to estimate and test gene diversities and fixation indices (version 2.9.3). 2001 [cited 2017 Sep 9]; Available from: http://www.unil.ch/izea/softwares/fstat.html

Grant WAS, Bowen BW. Shallow population histories in deep evolutionary lineages of marine fishes: insights from sardines and anchovies and lessons for conservation. J Hered [serial on the internet]. 1998; 89(5):415-26. Available from: https://doi. org/10.1093/jhered/89.5.415

Hall TA. BioEdit: a user-friendly biological sequence alignment editor and analysis program for Windows 95/98/NT. Nucl Acid S. 1999; 41:95-98.

Hilsdorf AWS, Azeredo-Espin AML, Krieger MH, Krieger JE. Mitochondrial DNA diversity in wild and cultured populations of Brycon opalinus (Cuvier, 1819) (Characiformes, Characidae, Bryconinae) from the Paraíba do Sul Basin, Brazil. Aquaculture [serial on the internet]. 2002; 214(1-4):81-91. Available from: https://doi.org/10.1016/S0044-8486(02)00132-1

Hoffmann AC, Orsi ML, Shibatta OA. Fish diversity in the UHE Escola Engenharia Mackenzie (Capivara) reservoir, Paranapanema River, upper Rio Paraná basin, Brazil, and the importance of large tributaries in its maitenance. Iheringia Sér Zool [serial on the internet]. 2005; 95(3):319-25. Available from: http://dx.doi.org/10.1590/S0073-47212005000300012

Instituto Chico Mendes de Conservação da Biodiversidade (Org.). Livro Vermelho da Fauna Brasileira Ameaçada de Extinção: Volume VI - Peixes. Brasília: ICMBio; 2018.

Librado P, Rozas J. DnaSP v5: A software for comprehensive analysis of DNA polymorphism data. Bioinformatics. 2009; 25(11):1451-52.

Lima FCT. A revision of the cis-andean species of the genus Brycon Müller \& Troschel (Characiformes: Characidae). Zootaxa. 2017; 4222(1):1-189.

Lima FCT, Albrecht MP, Pavanelli CS, Vono V. Threatened fishes of the world: Brycon nattereri Günther, 1864 (Characidae). Environ Biol Fish [serial on the internet]. 2008; 83(2):207-8. Available from: http://dx.doi.org/10.1007/s10641-007-9319-1

López L. Genetic variability and population structure of dorada (Brycon moorei sinuensis Dahl) in the Sinú River, Córdoba, Colombia. Lakes Reserv Res Manag [serial on the internet]. 2006; 11(1):1-7. Available from: https://doi.org/10.1111/ j.1440-1770.2006.00289.x

Lopes CM,Almeida FS, Orsi ML, Britto SGC, Sirol RN, Sodré LMK. Fish passage ladders from Canoas Complex - Paranapanema 
River: evaluation of genetic structure maintenance of Salminus brasiliensis (Teleostei: Characiformes). Neotrop Ichthyol [serial on the internet]. 2007; 5(2):131-38. Available from: http://dx.doi.org/10.1590/S1679-62252007000200006

Luikart G, Allendorf FW, Cornuet JM, Sherwin WB. Distortion of allele frequency distributions provides a test for recent population bottlenecks. J Hered [serial on the internet]. 1998; 89(3):238-47. Available from: https://doi.org/10.1093/ jhered/89.3.238

Luikart G, Cornuet JM. Empirical evaluation of a test for identifying recently bottlenecked populations from allele frequency data. Conserv Biol [serial on the internet]. 1998; 12(1):228-37. Available from: https://doi.org/10.1111/j.15231739.1998.96388.x

Matsumoto CK, Hilsdorf AWS. Microsatellite variation and population genetic structure of a Neotropical endangered Bryconinae species Brycon insignis Steindachner, 1877: Implications for its conservation sustainable management. Neotrop Ichthyol [serial on the internet]. 2009; 7(3):395402. Available from: http://dx.doi.org/10.1590/S167962252009000300006

McCusker MR, Bentzen P. Positive relationships between genetic diversity and abundance in fishes. Mol Ecol [serial on the internet]. 2010; 19(22):4852-62. Available from: https://doi. org/10.1111/j.1365-294X.2010.04822.x

Meyer A, Kocher TD, Basasibwaki P, Wilson AC. Monophyletic origin of Lake Victoria cichlid fishes suggested by mitochondrial DNA sequences. Nature [serial on the internet]. 1990; 347:55053. Available from: https://dx.doi.org/10.1038/347550a0

Mikich SB, Bérnils RS. Livro Vermelho da Fauna Ameaçada no Estado do Paraná. Curitiba: Instituto Ambiental do Paraná; 2004.

Oyakawa TO, Menezes NA, Shibatta OA, Lima FCT, Langeani F, Pavanelli CS, Nielsen DTB, Hilsdorf AWS. Peixes de água doce. In: Bressan PM, Kierulf MCM, Sugieda AM, editors. Fauna ameaçada de extinção no Estado de São Paulo: vertebrados. São Paulo: Fundação Parque Zoológico de São Paulo; 2009. p.349-424.

Pavanelli CS, Graça WJ, Zawadzki CH, Britski HA, Vidotti AP, Avelino GS, Veríssimo S. Fishesfromthe Corumbá Reservoir, Paranaíba River drainage, upper Paraná River basin, State of Goiás, Brazil. Check List [serial on the internet]. 2007; 3(1):58-64. Available from: http://dx.doi.org/10.15560/3.1.58

Piry S, Luikart G, Cornuet JM. BOTTLENECK: A computer program for detecting recent reductions in the effective population size using allele frequency data. J Hered [serial on the internet]. 1999; 90(4):502-03. Available from: https://doi. org/10.1093/jhered/90.4.502

Pompeu PS, Reis LS, Gandini CV, Souza RCR, Favero JM. The ichthyofauna of upper rio Capivari: defining conservation strategies based on the composition and distribution of fish species. Neotrop Ichthyol [serial on the internet]. 2009; 7(4):659-66. Available from: http://dx.doi.org/10.1590/S167962252009000400015

Pritchard JK, Stephens M, Donnelly P. Inference of population structure using multi locus genotype data. Genetics. 2000; 155(2):945-59.

Raymond M, Rousset F. GENEPOP (version 1.2): population genetics software for exact tests and ecumenicism. J Hered. 1995; 86(3):248-49.

Reed DH, Briscoe DA, Frankham R. Inbreeding and extinction: the effect of environmental stress and lineage. Conserv Genet [serial on the internet]. 2002; 3(3):301-7. Available from: https://doi.org/10.1023/A:1019948130263

Rice WR. Analyzing tables of statistical tests. Evolution [serial on the internet]. 1989; 43(1):223-25. Available from: http://dx.doi. org $/ 10.2307 / 2409177$

Rogers AR, Harpending H. Population growth makes waves in the distribution of pairwise genetic differences. Mol Biol Evol [serial on the internet]. 1992; 9(3):552-69. Available from: https://doi.org/10.1093/oxfordjournals.molbev.a040727

Rosa RS, Lima FCT. Peixes. In: Machado ABM, Drummond GM, Paglia AP, editors. Livro vermelho da fauna brasileira ameaçada de extinção. Belo Horizonte: Fundação Biodiversitas; 2008.

Rosenberg NA. DISTRUCT: A program for the graphical display of population structure. Mol Ecol Notes [serial on the internet]. 2004; 4(1):137-38. Available from: https://doi.org/10.1046/ j.1471-8286.2003.00566.x

Sanches A, Galetti-Jr PM. Microsatellites loci isolated in the freshwater fish Brycon hilarii. Mol Ecol Notes [serial on the internet]. 2006; 6(4):1045-46. Available from: https://doi. org/10.1111/j.1471-8286.2006.01427.x

Sanches A, Galetti-Jr PM. Genetic evidence of population substructuring in the freshwater fish Brycon hilarii. Braz J Biol [serial on the internet]. 2007; 67(4):889-95. Available from: http://dx.doi.org/10.1590/S1519-69842007000500012

Sanches A, Galetti-Jr PM. Population genetic structure revealed by a school of the freshwater migratory fish, Brycon hilarii. Lat Am J Aquat Res [serial on the internet]. 2012; 40(2):408-17. Available from: http://dx.doi.org/10.3856/vol40-issue2-fulltext-15

Sanches A, Galetti-Jr PM, Galzerani F, Derazo J, Cutilak-Bianchi B, Hatanaka T. Genetic population structure of two migratory freshwater fish species (Brycon orthotaenia and Prochilodus argenteus) from the São Francisco River in Brazil and its significance for conservation. Lat Am J Aquat Res [serial on the internet]. 2012; 40(1):177-86. Available from: http://doi. org/10.3856/vol40-issue1-fulltext-17

Santos MCF, Ruffino ML, Farias IP. High levels of genetic variability and panmixia of the tambaqui Colossoma macropomum (Cuvier, 1816) in the main channel of the Amazon River. J Fish Biol [serial on the internet]. 2007; 71:33-44. Available from: https://doi.org/10.1111/j.1095-8649.2007.01514.x

Schuelke M. An economic method for the fluorescent labelling of PCR fragments. Nat Biotechnol [serial on the internet]. 2000; 18(2):233-34. Available from: http://dx.doi.org/10.1038/72708

Shibatta OA, Gealh AM, Bennemann ST. Ictiofauna dos trechos alto e médio da bacia do rio Tibagi, Paraná, Brasil. Biota Neotrop [serial on the Internet]. 2007; 7(2):125-34. Available from: http://www.biotaneotropica.org.br/v7n2/pt/ abstract?article+bn02107022007

Slatkin M, Hudson RR. Pair wise comparisons of mitochondrial DNA sequences in stable and exponentially growing populations. Genetics. 1991; 129(2):555-62.

Tajima F. Statistical method for testing the neutral mutation hypothesis by DNA polymorphism. Genetics. 1989; 123(3):585-95.

Thompson JD, Higgins DG, Gibson TJ. CLUSTAL W: improving the sensitivity of progressive multiple sequence alignment through sequence weighting, position-specific gap penalties and weight matrix choice. Nucleic Acid Res. 1994; 22(22):467380.

Van Oosterhout C, Hutchinson WF, Wills DPM, Shipley P. MICRO-CHECKER: software for identifying and correcting genotyping errors in microsatellite data. Mol Ecol Notes [serial 
on the internet]. 2004; 4(3):535-38. Available from: http:// dx.doi.org/10.1111/j.1471-8286.2004.00684.x

Viana D, Zawadzki CH, Oliveira EF, Vogel HF, Graça WJ. Structure of the ichthyofauna of the Bonito River, Ivaí River basin, upper Paraná River system, Brazil. Biota Neotrop [serial on the Internet]. 2013; 13(2):218-26. Available from: http:// dx.doi.org/10.1590/S1676-06032013000200021

Vianna NC, Nogueira MG. Ichthyoplankton and limnological factors in the Cinzas River - an alternative spawning site for fishes in the middle Paranapanema River basin, Brazil. Acta Limnol Bras. 2008; 20(2):139-51.

Vieira F, Santos GB, Alves CBM. A ictiofauna do Parque Nacional da Serra do Cipó (Minas Gerais, Brasil) e áreas adjacentes. Lundiana. 2005; 6:77-87.

Vitorino Júnior OB, Lopes KS, Pelicice FM. Abundância e estrutura de comprimento de Brycon nattereri (Osteichthyes, Bryconidae), uma espécie de peixe ameaçada do Brasil central. Acta Sci Biol Sci. 2014; 36(4):421-25.
Wu FQ, Shen SK, Zhang XJ, Wang YH, Sun WB. Genetic diversity and population structure of an extremely endangered species: the world's largest Rhododendron. AoB Plants [serial on the Internet]. 2015; 7:plu082. Available from: https://doi. org/10.1093/aobpla/plu082

Yeh FC, Yang RC, Boyle TBJ. POPGENE (version 1.32): Microsoft Windows-based freeware for population genetic analysis. Edmonton: University of Alberta; 1999. (c) (i)

Submitted May 29, 2018

Accepted January 23, 2019 by Guillermo Ortí 